Florida International University FIU Digital Commons

\title{
Re-Imagining the Victorian Classics: Postcolonial Feminist Rewritings of Emily Brontë
}

Yannel Celestrin

ycele002@fiu.edu

DOI: $10.25148 /$ etd.FIDC006529

Follow this and additional works at: https://digitalcommons.fiu.edu/etd

Part of the French and Francophone Literature Commons, Literature in English, Anglophone outside British Isles and North America Commons, Literature in English, North America Commons, Literature in English, North America, Ethnic and Cultural Minority Commons, and the Other English Language and Literature Commons

\section{Recommended Citation}

Celestrin, Yannel, "Re-Imagining the Victorian Classics: Postcolonial Feminist Rewritings of Emily Brontë" (2018). FIU Electronic Theses and Dissertations. 3665.

https://digitalcommons.fiu.edu/etd/3665 


\title{
FLORIDA INTERNATIONAL UNIVERSITY
}

\author{
Miami, Florida
}

\section{RE-IMAGINING THE VICTORIAN CLASSICS: POSTCOLONIAL FEMINIST REWRITINGS OF EMILY BRONTË}

\author{
A thesis submitted in partial fulfillment of \\ the requirements for the degree of \\ MASTER OF ARTS \\ in \\ ENGLISH \\ by \\ Yannel M. Celestrin
}

2018 
To: Dean Michael R. Heithaus

College of Arts, Sciences and Education

This thesis, written by Yannel M. Celestrin, and entitled Re-Imagining the Victorian Classics: Postcolonial Feminist Rewritings of Emily Brontë, having been approved in respect to style and intellectual content, is referred to you for judgment.

We have read this thesis and recommend that it be approved.

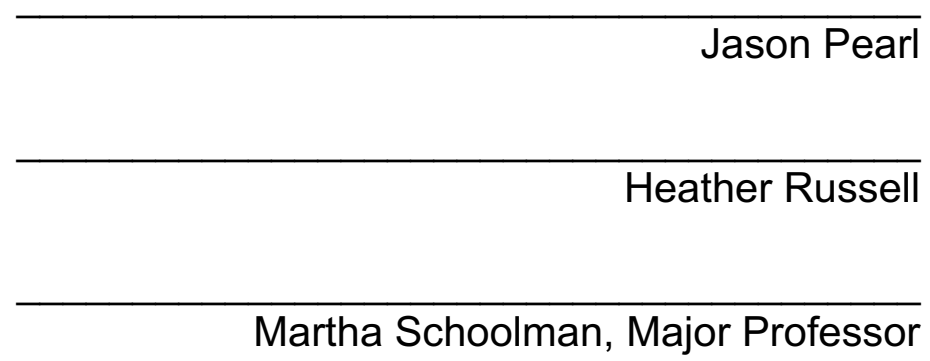

Date of Defense: March 27, 2018

The thesis of Yannel M. Celestrin is approved.

Dean Michael R. Heithaus Arts, Sciences and Education

Andrés G. Gil Vice President for Research and Economic Development and Dean of the University Graduate School

Florida International University, 2018 
ABSTRACT OF THE THESIS

RE-IMAGINING THE VICTORIAN CLASSICS: POSTCOLONIAL FEMINIST REWRITINGS OF EMILY BRONTË

by

\author{
Yannel M. Celestrin
}

Florida International University, 2018

Miami, Florida

\title{
Professor Martha Schoolman, Major Professor
}

Through a post-structural lens, I will focus on the Caribbean, specifically

Cuba, Guadeloupe, Marie-Galante, and Roseau, and how the history of colonialism impacted these islands. As the primary text of my thesis begins during the Cuban War of Independence of the 1890s, I will use this timeframe as the starting point of my analysis. In my thesis, I will compare Emily Brontë's Wuthering Heights and Maryse Condé's Windward Heights. Specifically, I will examine Condé's processes of reimagining and rewriting Brontë's narrative by deconstructing the notions of history, race, gender, and class. I will also explore ways in which Condé disrupts the hegemonic and linear notions of narrative temporality in an attempt to unsilence the voices of colonized subjects. I argue that Condé's work is a significant contribution to the practice of rewriting as well as to the canon of Caribbean literary history. I argue that the very process of rewriting is a powerful mode of resistance against colonizing powers and hegemonic discourse. 


\section{TABLE OF CONTENTS}

CHAPTER

PAGE

Re-Imagining the Victorian Classics: Postcolonial Feminist Rewritings of Emily

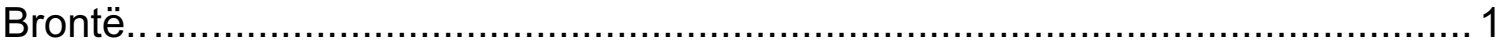

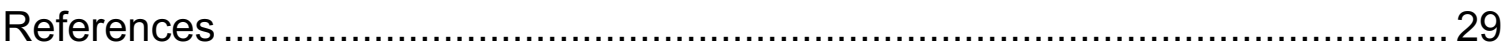


Re-Imagining the Victorian Classics: Postcolonial Feminist Rewritings of Emily Brontë

Post-colonialism is an academic discipline that analyzes and responds to the social, political, and cultural consequences of colonialism in a specific space. From 1776 through the middle of the twentieth century, movements of revolution and independence against colonial powers were prevalent throughout the world. During this time of conflict against the colonizer, there were many forces attempting to combat colonial powers, especially writers, who played a pivotal role in this global revolution. As cultural spokespeople for this call-to-action against imperial powers, postcolonial writers have attempted to reexamine and reinvent colonial literature by modifying and subverting the prominent social discourse between the colonizer and the colonized. In other words, they question how types of "knowledges" or epistemologies are produced in hopes of decentering imperial discourse, a discourse that represents colonized subjects as passive and malleable beings incapable of producing and telling their own histories.

Terms such as colonialism, post-colonialism, neocolonialism, and decolonization are central to my analysis. As such, I will use Ania Loomba's Colonialism/Postcolonialism ${ }^{1}(2005)$ as my discursive basis. Loomba begins by analyzing the definitions of central terms, such as colonialism, which is defined as "a body of people who settle in a new locality, forming a community subject to

\footnotetext{
${ }^{1}$ In this formative text, Loomba provides a comprehensible guide to the historical and theoretical dimensions of colonial and postcolonial studies.
} 
or connected with the parent state" (19). She notably points out that this definition does not include anyone other than the colonizers, who are labeled as "the body of people." There is no implication of conquest, domination, or even an encounter. She goes on to define post-colonialism as the contestation of colonial dominance and legacies of colonialism. In other words, it is a process in which colonized subjects attempt to disengage with colonial powers. She then defines neocolonialism (starting post-WWII) as a time during which colonial powers maintain indirect control of nations through economic intervention and "puppet regimes" (Loomba 19). Finally, Loomba describes decolonization as a state during which people fought and continue to fight against colonial rule. Those taking part in this revolution work to challenge, revise, and subvert ideologies and mythologies of race, gender, and class. Postcolonial writers can be seen as participating in this revolution.

One such writer is scholar Aimé Césaire, whose work participates in this subversion of colonial discourse. In Discourse on Colonialism, Césaire composed a historical prose poem which details and fights against the realities of colonialism. Published in 1950, a time when colonial powers were collapsing and movements of decolonization were beginning, Césaire analyzes and questions the relationship between the colonizer and the colonized. He also provides his own understanding of colonialism, which is characterized by: "No human contact, but relations of domination and submission which turn the colonizing man into a classroom monitor, an army sergeant, a prison guard, a slave driver, and the indigenous man into an instrument of production" (Césaire 42). He calls the 
process of colonization as a "thingification" through which colonial discourse has historically and systematically converted living beings into "instruments of production" (Césaire 42).

Césaire's text, along with countless other writers of the Caribbean, show how literature itself is a way of approaching, subverting, and challenging dominant discourses of representation. One tradition through which postcolonial writers engage in this revolution against the colonizer is by rewriting classic literature. By partaking in this critical practice, writers have the opportunity not only to tell their own stories, but a multitude of stories from different perspectives. From Jean Rhys's Wide Sargasso Sea ${ }^{2}$ (1966) to Derek Walcott's “The Odyssey: A Stage Version" (1993), Caribbean authors have used rewriting as a technique to trouble colonial discourse.

As its reasons are complex and unique to each writer, it is important to first review some popular theories on this tradition of rewriting. Rewriting is theorized in Bill Ashcroft, Gareth Griffiths, and Helen Tiffin's text, The Empire Writes Back: Theory and Practice in Post-Colonial Literatures. Rewriting is defined as a form of resistance against colonial discourse. The practice is described as "a view to restructuring European 'realities' in post-colonial terms, not simply by reversing the hierarchical order, but by interrogating the philosophical assumptions on

\footnotetext{
${ }^{2}$ Rhys's Wide Sargasso Sea is a rewriting of Charlotte Brontë's Jane Eyre (1847), written from the perspective of Bertha Mason (rechristened as Antoinette), Rochester's wife.

${ }^{3}$ Walcott's "The Odyssey: A Stage Version" is his retelling of Homer's Odyssey.
} 
which that order was based" (Ashcroft, Griffiths, \& Tiffin, 32). They evoke Salman Rushdie's words ${ }^{4}$ in explaining that rewriting is a technique that allows the Empire to write back to the imperial center. However, the model assumes that the canonical text is at the center, or the one true novel, while the new rewritten text is marginalized, only secondary to the "original" novel. In other words, this postcolonial theory presupposes a hierarchy of literature within the Western canon. Other theorists even regard the practice of rewriting as a form of weak imitation or plagiarism ${ }^{5}$.

These theories of rewriting, which privilege the "classic" text over the "secondary" text or define rewriting as plagiarism, have fallen short, not only when defining the process itself, but when also describing the relationship between the canonical text and the rewritten text. In this case, the relationship between the texts is assumed to be reductive. What these models and theories miss is that the act of rewriting challenges the very notions of authorial authority and authenticity. In many ways, whether it is appropriation or engagement, the process of rewriting invokes methods and forms of intertextuality, or, the everexpanding relation of texts. ${ }^{6}$

\footnotetext{
${ }^{4}$ The title The Empire Writes Back derives from Salman Rushdie's essay, "The Empire Writes Back with a Vengeance" (1982).

${ }^{5}$ Roger Little makes this argument in "Condé, Brontë, Duras, Beyala: Intertextuality or Plagiarism?"

6 "Intertextuality" was coined in the 1960s by Julia Kristeva. In her essay, "Word, Dialogue and Novel," she defines intertextuality as "a mosaic of quotations; any text is the absorption and transformation of another. The notion of intertextuality replaces that of intersubjectivity, and poetic language is read as at least double" (Kristeva 85, cited in Moi).
} 
One other aspect of rewriting that seems to be overlooked in postcolonial theory is the relationship between the postcolonial writer and the canonical text, insofar as the relationship that postcolonial writers have with literature from the European canon is not considered. Not only are these canonical texts part of the writers' literary and cultural tradition, but they are also sites of colonial domination. In other words, imposing Western literary studies in colonies is a way to impart specific Western values, in which case constructs the Western European culture as superior. In rewriting, not only are these writers paying tribute to their predecessors, but they are also attempting to counter the very assumptions upon which the texts are based. In other words, rewriting should be viewed as a mode of resistance that dismantles meaning, renegotiates colonial discourse, and redirects the canon itself.

A significant addition to the tradition of rewriting in Caribbean literature is Guadeloupean writer Maryse Condé's novel Windward Heights, in which she reimagines Emily Brontë's Victorian novel, Wuthering Heights. However, before examining this work in detail, it is important to examine the overall scope of Condë's oeuvre. Her literary project or novelistic architecture is concerned primarily with narratology or narrative structure, a failed return to an origin and the artificiality of an essential origin (specifically, within her work, she questions an African origin), and the privileging of Eurocentric male genealogies. All in all, Condé is concerned with the formation of Caribbean (specifically diasporic ${ }^{7}$ )

\footnotetext{
${ }^{7}$ I borrow the definition of diaspora from Njeri Githire's Cannibal Writes: Eating Others in Caribbean and Indian Ocean Women's Writing, in which she refers to diasporic peoples as "the plural societies formed out of the fusion of peoples
} 
histories and subversive narratives. For example, in Crossing the Mangrove (1995), the mangrove serves as a symbol or metaphor for the Caribbean, in which lineages and histories of violence and identities are constantly interlocking. The plot of the novel (which revolves around the death of the protagonist, the mysterious Francis Sancher), unravels through multiple and contradictory accounts of several characters. A similar narratology which privileges multiple narrators instead of one can be traced to several of Condé's novels, including Windward Heights. Another common trope of her work is the critique of one central genealogy. For instance, in Desirada ${ }^{8}(2000)$, a novel set between Guadeloupe, France, and the United States, the protagonist, Marie-Noëlle, desperately searches for the origins of her family, only to discover that her genealogy is fragmented and scattered. A singular genealogy is also disputed in Hérémakhonon $^{9}$ (1982), during which a Guadeloupean woman (Veronica Mercier) embarks on a journey to Africa to "recuperate" her black identity, but ultimately fails to return to her "ancestral origin." Furthermore, Condé continues the tradition of rewriting in I, Tituba, Black Witch of Salem ${ }^{10}$ (1994), in which Tituba, an enslaved West Indian, not only tells the story of Nathaniel Hawthorne's

indigenous to these regions with newcomers through chattel slavery, the plantation economy and labor migrations... Diaspora also refers to communities formed out of the movements of Caribbean and Indian Ocean peoples to regions outside of their home territories" (203).

${ }^{8}$ The title of the novel, Desirada, derives its name from La Désirade, an island in Guadeloupe, which is also present in Windward Heights.

${ }^{9}$ The title is from a Malinké word which means "to wait for happiness."

${ }^{10}$ This novel is a rewriting of Nathaniel Hawthorne's The Scarlet Letter (1850). 
The Scarlet Letter, but also unravels her own personal history. The scope of her texts is mostly concerned with hybrid forms of identity production that interpenetrate and influence each other. Condé's characters, enamored with the idea of a pure identity, often embark on a journey to find their "essential identities;" however, each quest is a failed return to origin. Throughout her works, she uses the genre of historical fiction to explore the problematic legacy of the African diaspora, particularly the legacy of slavery and colonialism, not only in her native French Caribbean, but the Caribbean in general.

In my thesis, I will compare Emily Brontë's Wuthering Heights and Maryse Condé's Windward Heights. Specifically, I will examine Condé's processes of reimagining and rewriting Brontë's narrative by deconstructing the notions of history, race, gender, and class. I will also explore ways in which Condé disrupts the hegemonic and linear notions of narrative temporality in an attempt to unsilence the voices of colonized subjects. I argue that Condé's work is a significant contribution to the practice of rewriting as well as to the canon of Caribbean literary history. I intend to prove that the very process of rewriting is a powerful mode of resistance against colonizing powers and hegemonic discourse. 
Understanding the Novels: Emily Brontë's Wuthering Heights \& Maryse Condé's Windward Heights

Published in 1847, Wuthering Heights is a canonical Victorian text that follows the story of doomed lovers Catherine Earnshaw, the daughter of a white family, and Heathcliff, (described as a gypsy-like man because of his dark skin) who is adopted by the Earnshaw family. Throughout their childhood, Catherine and Heathcliff develop a strong relationship. However, Catherine decides to marry Edgar Linton, her wealthy white neighbor, in order to raise her status in society. Her decision not only binds the two neighboring families together, but it also spearheads the events of the novel, including Heathcliff's revenge on the families. The reason for the tumultuous end of Catherine and Heathcliff's relationship does not lie in their feelings for one another, but rather, in their adherence to the imposed Victorian standards of gender, class, and race. These social scripts and norms cause not only the failure of their relationship, but their eventual deaths. Their story is relayed to the readers through Lockwood, the tenant of Thrushcross Grange (the Linton's residence). However, he hears the story from Nelly Dean, the main servant who worked in both households.

The social observations and critiques that Bronte explores in her novel are explicitly displayed in Condé's novel, Windward Heights. ${ }^{11}$ Published in French in

\footnotetext{
${ }^{11}$ The French title, La Migration des Coeurs, translates as "the migration of hearts."
} 
1995, Condé's novel throws Brontë's Victorian characters into the chaotic world of the colonial, postcolonial, and neocolonial ${ }^{12}$ Caribbean.

Set in the second half of the nineteenth-century just after the abolition of slavery, Condé presents a narrative that addresses the complicated transnational consequences of colonialism in Caribbean colonies and how it informs the lives of its inhabitants. Brontë's characters are thusly reimagined within these new parameters. For example, Heathcliff is now Razyé, a dark-skinned boy with an unknown past. Catherine is now Cathy, described in the novel as a "mulatta." The physical spaces are also reimagined within this context: Wuthering Heights is now l'Engoulvent and Thrushcross Grange is now Belles-Feuilles, a plantation. The Lintons become the de Linseuils, with son Aymeric (Edgar) and daughter Irmine (Isabella).

Condé opens her novel by stating: "To Emily Brontë / Who I hope will approve of this interpretation of her / masterpiece. Honor and respect!" In my reading of this dedication, Condé uses the word "interpretation" to claim that she is engaging in the process of rereading, reimagining, and rewriting in an attempt to release the voices that Brontë and history have silenced. She takes Brontë's Victorian gothic romance and transforms it into a text that can be read as a work of African cosmology, historical fiction, Caribbean gothic romance, and a comingof-age novel. All in all, Windward Heights transposes issues of identity politics

\footnotetext{
${ }^{12}$ I am engaging in a postcolonial reading of both Brontë's and Condé's texts, as I am working primarily through postcolonial theories. However, it is important to note that Condé's text follows the processes of colonialism, post-colonialism, and neocolonialism in Cuba, Guadeloupe, and Roseau. In my analysis, I will be using "postcolonial" as an umbrella term which includes these other colonial terms.
} 
from $19^{\text {th }}$ century England to the $20^{\text {th }}$ century Caribbean. As such, the main focus of the story is not the romance between Cathy and Razyé, but the social, political, and cultural issues that plague the Caribbean colonies. As Condé herself explains in an insightful interview by Rebecca Wolff through $B O M B$ magazine: "she [Cathy] chooses to marry a white man... and in doing so weaves herself and her descendants into the fabric of the island's social and political upheaval... that is shown to be an inextricable part of any fate: romantic, tragic, personal, national, or otherwise" (Condé 1999). The decisions that the characters make are not only influenced by the environment in which they live, but in turn, these decisions have serious ramifications for others around them. In short, the novel is not only about the personal histories and lives of each character, but about how all of the characters are connected (and at times, impact) the history of the colonies they inhabit.

Rebelling against Mythologies of Race and Gender: A Post-Structural \& Asynchronous Reading of Windward Heights and Wuthering Heights

By engaging in a close reading of Windward Heights, I will use a poststructural approach to analyze the mythologies of race and gender to which the characters adhere. For my analysis, I will be using Reclaiming Difference: Caribbean Women Rewrte Postcolonialism by Carine M. Mardorossian (2005) as a theoretical basis. Mardorossian begins her text by presenting two phases of postcolonial literature. The first phase, from the decolonizing era of the $1950 \mathrm{~s}$ through the 1960s, is defined by "how postcolonial rewritings write against 
colonial culture" (Mardorossian 7). The second phase, starting at the late 1960s, is concerned with "how they write from within or in symbiosis with the dominant discourse whose claims they undermine internally rather than oppositionally" (Mardorossian 7). She urges for a third phase in which identities are reimagined as in "constant flux rather than fixed, as multiple rather than dualistic" (3).

Specifically, Mardorossian pushes for the notion of race to be re-characterized and reread through other categories of identification, such as gender and class. This intersectional understanding or "reading" of identity categories is prevalent in both Condé's and Brontë's texts. The characters' relation and identification to a certain race changes as they are "blackened" or "whitened"13 according to their shifting relations to others. The question of racial identification and affiliation is not about whether it happens, but when it happens.

For instance, when the readers are first introduced to Condé's Cathy, she is so dark that she cannot "pass" as white: "she was the color of hot syrup left to cool in the open air, with black hair like threads of night and green eyes" (Condé 19). She is described alongside her brother, Justin, who can "pass" as white, but with a bit of work: "the boy was somewhat sad and taciturn, with a fair skin, fair enough for him to earn a place for himself in white folks' company through sheer hard work" (Condé 18). Although Justin visually resembles whiteness, he is shunned by the upper Creole class, as he is poor.

\footnotetext{
${ }^{13}$ A similar understanding of the intersectionality of race, gender, and class is seen in Condé's Crossing the Mangrove, in which one of the characters comments that the "popular imagination... whitens or blackens a man until he is unrecognizable" (98).
} 
It is his sister, Cathy, who cements her place in white society by marrying Aymeric, a white Creole plantation owner. Her transformation from a "mulatta" to a "white" woman began when she was invited to spend one month with Aymeric's sister, Huberte de Linsseuil. During Cathy's stay in the plantation, her black identity is constantly challenged. Being under a constant white gaze, Cathy had no choice but to shed her black skin and identity in order to transform into an acceptable white Creole, like Huberte. Her transformation is noted when she returns to her home: "the wild girl...was dead and buried. A respectable young girl had taken her place. She pouted in just the right way... she had pinned up and rolled into a chignon her thick black hair that used to tumble down her back. She worried about her complexion, shaded herself under a parasol and hid from the sun" (Condé 35). During her stay in Belles-Feuilles, Cathy, a Creole, is being domesticated according to the ideals of white womanhood. Taming her hair and worrying about her complexion are not only the result of a rigid domestic education, but her forced adherence to whiteness. In other words, her fluctuation in color from her childhood to her teenage years should be read alongside her crossing and recrossing of class and gender boundaries.

Later on, when Cathy marries Aymeric, she is described as "pale," further disrupting previous visual cues pointing to her dark skin color (Condé 50). Throughout their marriage, Cathy's skin continues to "lighten;" however, this change is put to a halt when she dies after giving birth to her daughter, Cathy II. During Cathy l's wake, her skin becomes even darker than when she was a child. 
It seems that she physically reverted to the color she was before meeting Aymeric and marrying into white Creole society:

By the magic of death, in a single stroke she had regained her lost beauty and youth and looked like the girl she used to before wanting to be admitted at any price to polite society... First of all the color of her skin was not white. It was as if her black blood could no longer be contained and was taking its revenge. Victorious, it was flooding through her. It thickened her facial features, distended her mouth, giving a mauve touch to her lips, and with the stroke of a pencil redefined the arch of her eyebrows. It did wonders for her figure. What was this girl of African descent doing here, you might well have asked, and how did she get laid out on a sheet surrounded by all these white Creoles trying to put on an appropriate face for the occasion? (Condé 84)

This passage points to the fact that race is not a fixed identity determined by ancestry, but rather, it is a "fluid variable that changes in different contexts and different times" (Mardorossian 16). The physical body, therefore, is not a constant, but a variable. ${ }^{14}$ Not only is race an unstable category, but it constantly intersects with gender, class, and other categories of identification.

Cathy's transformation illustrates that her identities as a "mulatta" or a white Creole are performances. It would be useful, then, to turn to gender theorist Judith Butler's text, Gender Trouble: Feminism and the Subversion of Identity

\footnotetext{
${ }^{14}$ A similar crossing is evident in Wide Sargasso Sea, during which Antoinette is "blackened" when she takes charge of sexual relations with husband.
} 
(1990). In this text, Butler argues that gender is not a biological or natural category, but an improvised performance:

gender is not a noun, but neither is it a set of free-floating attributes, for we have seen that the substantive effect of gender is performatively produced and compelled by the regulatory practices of gender coherence. Hence, within the inherited discourse of the metaphysics of substance, gender proves to be performative - that is, constituting the identity is it purported to be. In this sense, gender is always a doing, though not a doing by a subject who might be said to preexist the deed (34).

In other words, gender is a performance that is determined not only by the person in question, but by the societal ideals by which that person willingly or unwillingly follows. The performances of Cathy's femininity and whiteness stem from the social scripts of the society that she is trying to please, which in Condé's novel, is the upper white Creole class. By marrying into this upper class, Mardorossian argues that Cathy's "phenotype reflects her social status rather than determines it" (39). Determining, therefore, that the characters' relation and identification with a certain race or other form of identity is augmented or altered by their social status. Hence, it is impossible to read or understand race alone. Condé's text presents race as always in relation to other categories of identification.

Ultimately, Cathy developed a duplicitous identity as a response to her environment. In fact, she made the decision to marry Aymeric to cement her 
whiteness and therefore secure her place in society. When discussing her decision with Nelly, she states that:

It's as if there were two Cathys inside me and there always have been, ever since I was little. One Cathy who's come straight from Africa, vices and all. The other Cathy who is the very image of her white ancestor, pure, dutiful, fond of order and moderation. But this second Cathy is seldom heard, and the first always gets the upper hand (Condé 40).

This passage speaks to the Négritude movement, ${ }^{15}$ which Condé criticizes in her essay, "Order, Disorder, Freedom, and the West Indian Writer" (1993). In her argument, Condé gives credit to the Négritude movement for changing the way Caribbean people see themselves. However, she also points to the myth that it perpetuates, a myth of rootedness in a shared racial past. However, to return to this "essential" African past is impossible, as the idea of an African rootedness is artificial as such. Condé is suspicious of the idealization of Africa that was perpetuated within the Négritude movement. While it is problematic, it is important to note that both arguments, the Négritude movement as well as Condé's questioning and criticism of it, is needed. This idea of rootedness creates an impossible choice between whiteness and blackness, Europe and Africa. This is the choice that Cathy struggles with for the whole narrative: she

\footnotetext{
${ }^{15}$ Founded by writers such as Aimé Césaire and Léopold Senghor, this literary movement took place during the 1930s and 1940s, during which black writers joined together to assert their cultural identity. See Micklin.
} 
must either repress or reclaim her African ancestry. Her indecision and crossing between both identities ultimately leads to her dementia and death.

The struggle against the mythology of a pure identity, white, black, or otherwise, is not only relevant in Windward Heights, but also in the lives and works of female Caribbean writers. This argument is made in Condé's essay, "The Stealers of Fire: The French-Speaking Writers of the Caribbean and Their Strategies of Liberation" (2004). When discussing the oppressive mythologies that attempt to dictate the lives of female Caribbean writers, Condé states that: this generation confronts Africa - first the shameful face of Caribbean identity, then the womb, the mother lode... they undertake a physical journey back to the continent. Mother Africa, alas, is nothing but a wicked stepmother. Their search ends in disillusionment, bitterness, and failure...this bitter destruction of myths - the myth of the spiritual mother, the myth of the biological mother - aims for total liberation (163).

She argues that women writers, and if read next to Cathy's passage, her characters as well, must rid themselves of myths that would bind, confine, and paralyze them otherwise.

Race is a significant category of identification, which must be understood in terms of and in relation to other categories of identification. This is not only evident in Condé's novel, but in Brontë's text as well. An asynchronous reading of the texts illustrates that "Condé's rewriting helps make visible patterns of racial meaning that are embedded in the Victorian source-text and that constitute a 
cultural ground common to both the Victorian and Caribbean texts and contexts" (Mardorossian 19). In other words, Condé's rewriting shows how Heathcliff and Cathy's romance epitomizes the inseparability of race-class-gender discourses. For instance, Heathcliff and Cathy's racial identities fluctuate as their relation to one another changes. Their racial identifications also flow according to their transgressions of socially prescribed roles. For example, the vocabulary used to describe Heathcliff changes according to his context. When Heathcliff is first brought to Wuthering Heights, Mr. Earnshaw (his adoptive father) describes him as "dark almost as if it came from the devil itself" (Brontë 15). Later, Nelly, the housemaid, describes him as "a gypsy brat... who kept repeating some gibberish nobody could understand" (Brontë 51). Likewise, when Lockwood first encounters Heathcliff, he describes him as "A dark-skinned gypsy" (Brontë 27). Through these examples, it is clear that Heathcliff's racial identity is ambiguous, at best. His introduction to the estates of Wuthering Heights and Thrushcross Grange is filled with animosity and hatred because of his status as the "savage other." In other words, the Earnshaw and Linton families are intimidated and repulsed at the idea of miscegenation, of which Heathcliff is a product. In Brontë's novel, Heathcliff is always implicitly or explicitly understood through his dark skin. ${ }^{16}$ However, the degree of his "darkness" is determined by who is

\footnotetext{
${ }^{16}$ Ironically, cinematic and televised adaptations of Wuthering Heights always cast Heathcliff as white. The only time that he is unambiguously black is the Caribbeanization of his character, Razyé. It is not until Andrea Arnold's 2011 cinematic adaptation that Heathcliff is cast as black. See Valérie V. Hazette's Wuthering Heights on Film \& Television: A Journey Across Time and Cultures (2015).
} 
observing him and by his current social status. Heathcliff's ambiguous racial status is analyzed in Vinay Swamy's “Traversing the Atlantic: From Brontë's 'Wuthering Heights' to Condé's 'La Migration Des Cœurs.' It is important to note that when Heathcliff was rejected by Cathy, he disappeared for three years. Brontë does not reveal what he may or may not have done during this time. Instead, the inhabitants of the Yorkshire Moors only speculate, not only his past and heritage, but his absence. It is during this hiatus that Condé begins her novel. Swamy emphasizes the significance of Condé's starting point by stating that: "while Brontë's portrayal of alterity and difference, largely in the guise of Heathcliff, remains masked and, for the most part, left to the reader to deduce, Condé's critical engagement in this issue is brought out by the reterritorialization of Wuthering Heights and this allows for a discussion of the colonization of the Caribbean and its ramifications as such" (Swamy 65). In other words, Condé is able to unsilence the racial ambiguities that are prevalent throughout Brontë's novel.

Cathy's race similarly fluctuates throughout the narrative. During her childhood with Heathcliff, she is described as being a dirty, "half-savage" child. Notably, it is only when she is with Heathcliff that she is described in this manner. Similar to how Condé's Cathy is "domesticated" after her trip with the de Linsseuils, Brontë's Cathy undergoes a similar domestication after her training with the Lintons. When she returns from Thurshcross Grange after five weeks, Nelly notes that Cathy's hands were "wonderfully whitened with doing nothing and staying indoors" (Brontë 42). It seems that Cathy was darker and "dirty" 
when she was part of the lower class, especially when she was around Heathcliff. However, when she begins her ascension into the white upper class, her skin literally whitens. Race, along with other forms of identity categories, are fragmented, fluctuating, and meaningful. The racial discourse discussed in both novels should not be read in isolation from other categories of identification.

Disrupting Narrative Temporality: Re-Tellings of History

In his collection of essays entitled Caribbean Discourse (1989), Francophone scholar Édouard Glissant examines the psychological, sociological, and philosophical implications of colonialism in the Caribbean. In his chapter, "The Quarrel with History," Glissant questions what, or who's stories, are considered history: "History [with a capital $\mathrm{H}$ ] ends where the histories of those peoples once reputed to be without history come together. History is a highly functional fantasy of the West, originating at precisely the time when it alone 'made' the history of the World" (64). Historically, the "tellers" or "writers" of History are those in power. A similar argument is made in Cora Kaplan's Victoriana: Histories, Fictions, Criticism (2007), in which she describes history as a multi-faceted and multi-layered process. In other words, the process of recounting and passing down history is not comprised of "facts," but a "constellation of stories, images and interpretations" (Kaplan 17). Going against the idea of a monolithic history, Condé subverts the idea that there is one, singular form of history and/or truth throughout her novel. Firstly, the narratology of the novel shows that there is not one central way to tell history; instead, the histories of the characters as well as 
the islands are divulged in different ways by different narrators. Furthermore, the characters attempt to reimagine, rewrite, and retell history, which echoes Condé's own retelling of Wuthering Heights.

By rewriting Bronte's novel within specific historical and geographical parameters, Condé is able to introduce new dimensions of sociopolitical, racial, and gender issues that are not as prominent in Brontë's text. First, it is important to examine the geographical spaces in which the story unravels. Literary scholar Maria Cristina Fumagalli closely examines this context in her book titled Caribbean Perspectives on Modernity: Returning Medusa's Gaze. ${ }^{17}$ Part One begins in $\mathrm{Cuba}^{18}$ in 1898 during a time of great political turmoil. For example, in 1895, Cuba's sugar industry collapsed. The event was closely followed by a guerilla separation led by revolutionary leaders Jose Marti, Antonio Maceo, and Maximo Gomez. ${ }^{19}$ Shortly after, the Spanish-Cuban-American War ensued. ${ }^{20}$ Fumagalli argues that Condé composes her novel within these turbulent times to present "two different histories, a history of colonial and neocolonial North

\footnotetext{
${ }^{17}$ The chapter on Windward Heights is titled: "Scapegoating the Mulattos: Maryse Condé's La Migration Des Coeurs."

${ }^{18}$ The novel begins with the U.S. intervention in the Spanish-Cuba conflict of 1898 , which marks the beginning of $20^{\text {th }}$ century neocolonialism.

${ }^{19}$ It's important to note that this information does not come from Fumagalli's research, but from the novel.

${ }^{20}$ Fumagalli explains that the war began in 1898 when the North American battleship Maine arrived in Havana and killed 258 men in one explosion. The U.S. blamed Spain while Spain rejected any involvement in this event. This conflict then became a war of conquest which led to the American occupation of Cuba (57).
} 
Atlantic exploitation and domination, and a history of political insurgency and resistance" (57). Part Two takes us to Guadeloupe, where most of the story takes place. Part Three takes us to Marie-Galante, an island of Guadeloupe, while Part Four takes us to Roseau, Dominica, while Part Five takes us back to Guadeloupe. Through the novel, Condé creates a world where these islands are in close communication with another.

There is not one history that is central to the development of the novel or the development of the characters themselves. Instead, different versions of history are told through various perspectives. The organization of the novel itself is one example. The stories are told through 13 different perspectives, by people of different classes, genders, races, and ages. The narrators are: Nelly Raboteur (Condé's counterpart to Brontë's Nelly Dean), Justin, Lucinda Lucius, Irmine de Linsseuil, Mabo Julie, Sanjita the Housekeeper, Etiennise (Sanjita's daughter), Mabo Sandrine, Madhi, Romaine the Servant, Roro the Fisherman, Ada the Fishwife, and Cathy. Not only do each of the narrators relay a piece of the complicated relationship between Razyé and Cathy, and later the relationship between their children, Razyé II and Cathy II, but within this telling, they are also relaying their own personal lives, as well as the history of the islands. The histories of the islands themselves, however, are not told separately or treated as separate from the other; instead, the novel shows how each history is impacted by the other. For example, when Nelly is telling her tale of Razyé and Cathy's childhood, the narrative is interrupted and brought to the present with the explosion of the U.S. Maine battleship off the coast of Cuba. Therefore, there are 
two timelines and places at work here: one in Guadeloupe in the past, and the other in Cuba, in the present.

It is within this setting that the families are introduced. Nelly, faithful servant of Cathy's family, is one of our first narrators. For instance, in the first section of the novel which starts in Cuba, the history of the island is integral to the development of the story. For example, the Governor's Palace (or the "Palacio de los Capitanes Generales") is described as "an edifice recently completed after hundreds of slaves had worked on it for over half a century under the order of architects who had come all the way from Castile" (Condé 3). The building does not exist alone; instead, it is described to the reader through its construction. The detailed construction of the Governor's Palace, as well as the emphasis on the enslaved population that forcibly constructed it, echoes Glissant's conception of history as a multi-layered "lived experience" (10). For example, when describing the history of his native Martinique, Glissant emphasizes the landscape of the island as the teller of history:

Ruins of factories lurk there as a witness to the old order of the plantations... the ruins of the Dubuc Great House (Château Dubuc) where the slaves disembarked... and where slave prisons still lie hidden underground... So history is spread out beneath this surface, from the mountains to the sea, from north to south, from the forest to the beaches. Maroon resistance and denial, entrenchment and endurance, the world beyond and dream... It is all history (11). 
In sense of Martinique, and by extension the Caribbean, there is not one, singular history that tells their stories. The story of the construction of the Governor's Palace is not just the building itself, but who built it and at what cost.

Within this passage in Condé's novel, it is also revealed that Spain recently abolished slavery; however, this did not significantly alter the life conditions of blacks in the Caribbean: “The abolition of slavery hadn't changed anything at all, you know. It was still the rich white planters who laid down the law and the blacks who lived from hand to mouth" (Condé 19). The sentiment that the history of oppression and violence remained after the abolition of slavery is echoed by some of the narrators of the novel. Lucinda, for instance, begins her story by commenting on it: "For my generation, the end of slavery means nothing. It's the same sadness, the same wretchedness we've been chewing on for as long as we can remember" (Condé 67). These examples further show how narratives of history conflict. For instance, while slavery was legally abolished, this did not change the sociopolitical realities of the Caribbean.

While a multitude of characters live within the space of Bronte's novel, they are marginalized and silenced. In Brontë's text, the story is told by a servant, Nelly, who is herself a servant to the story she is telling. Her only role in the novel is to relay the events surrounding Heathcliff and Cathy's romance. While she at times is the narrator of the story, she is ultimately narrating the events to Lockwood, a tenant in Thrushcross Grange. Nelly's "story" is then recorded, and altered, by Lockwood. As Swamy argues, "The Russian-doll structure of the 
narrative where Mr. Lockwood's narrative - itself subordinate to the omniscient narrator - subsumes all the others, each within the other, creates this hierarchy within each voice is progressively less direct, and thus less powerful. In such a structure, it is easily conceivable that many voices are too weak to be noticed at all" (66). However, these forgotten voices are rediscovered and given new meaning within Condé's novel. As opposed to Brontë's Lockwood and Nelly, the purpose of the "marginal" characters are not to relay the story of Cathy and Razyé, but more importantly, to tell their own stories.

Condé illustrates this point in an interview with $B O M B$ Magazine, in which she states that "in a society like the Caribbean, who knows more than the servants about the construction of society, the details of society? Nobody ever asks them their opinion, but they are there, they are witnesses; they are the ones who see, they are the ones who arrange everything" (1999). Therefore, their status and role in the novel cannot be reduced to mere observers, but partakers of history, responsible for constructing and telling their stories.

For instance, the story unfolds through a series of narrations that are dictated by different people, such as Nelly, Lucinda Lucius, Mabo Sandrine, and Sanjita. ${ }^{21}$ These characters are all enslaved who work with both families. While they relay bits and pieces of the plot, they also reveal their own personal histories within the process. Not only do these characters relay their own histories, but

${ }^{21}$ Fumagalli states that "after 1854 ...slavery was 'replaced' by immigration usually under indenture arrangements...most of the immigrants who went to Guadeloupe were actually Indians" (62). Sanjita is an enslaved Indian who was brought to Guadeloupe to work in Belles-Feuilles. 
they critique the society in which they live. Lucinda, for instance, not only critiques her masters, but she also tells the story of how her family was enslaved:

The great house of Belles-Feuilles is the jail of my life. That's where I was born, where Estella, my maman, was born before me and Fanotte, the maman of my maman, as far back as Fankora, my Bambara ancestor, who was captured by some 'mad dogs in the bush outside the walls of Segu while she was returning from wash- ing her clothes as white as cotton in the waters of the Joliba ... She found herself captive, a wooden collar around her neck, being forced to march to the tip of Cap-Vert (Condé 67).

On a similar note, Sanjita also alludes to her family's history: "On 21 December 1867, the Allahabad set sail from the port of Calcutta for the island of Guadeloupe with Shashi, my father aboard" (Condé 157). By including characters who are not only from Guadeloupe, France, and Africa, Condé emphasizes the heterogeneous populations that inhabit the Caribbean.

Condé continues her critique of colonial relations on the island through the narrators. For example, Mabo Sandrine, the nanny of Cathy II (Aymeric and Cathy's daughter), is completely devoted to Cathy. Even after Cathy becomes an adult and leaves the Belles-Feuilles plantation, Mabo Sandrine follows her. Despite her devotion to Cathy II, she still still feels hatred for Aymeric, her master, who represents the old plantocracy. ${ }^{22}$ When expressing her frustration in

${ }^{22}$ According to Loomba, a plantation colony describes a system in which whites imported enslaved to grow crops. 
her chapter, "Mabo Sandrine's Tale," she states that "a master is a master. You can't love him. Sometimes the hatred I have for him stirs in my stomach and surges up to my mouth, fetid like the spit of a toad. It flows out in fiery abuse like lava from a volcano, as sharp as the blade of a knife" (Condé 196). Not only does she express this anger, but she also chooses to do something about that anger by participating in the revolution that is slowly building in Guadeloupe. At 60 years old, she begins to attend Socialist meetings and helps plot against the upper Creole class. Clearly, Condé's characters are not only telling their own stories, but they show complicated ways of conceptualizing themselves. Fumagalli argues that Condé reimagines these characters as storytellers in order "to record the social, racial, and cultural complexity and diversity of the Caribbean" (55). Therefore, the main story is not the doomed romance of Cathy and Razyé. Rather, the true story lies within the characters' struggles to survive within the postcolonial Caribbean.

Similar to Condé's retelling of Brontë's novel, the characters themselves reimagine not just their lives, but the histories of their countries. For instance, when Aymeric begins to court Cathy, Nelly attempts to comfort Razyé by inventing stories of their ancestors: "You know, you're handsome in your own way, with that Ashanti black skin, that fine curly hair and all those marks on your cheeks. Perhaps your ancestors were princes and princesses? Who knows what our parents were before we were brought here as slaves!" (Condé 30). By imagining their own family histories, Nelly and Razyé are able to have a sort of agency over their own lives. A similar reimagining and retelling of family histories 
is evident in the scene with Razyé II and his younger brother, Zoulou, would also invent stories of their heritages: "Before Christopher Columbus and his bunch of ruffians had looted the island, then a paradise of parrots, macaws and crested cranes... they re-enacted the battles of old. They were always victorious and rewrote history back to front" (Condé 128). By reimagining their family's histories, the characters in these examples are actively resisting white colonial discourse. When explaining why the Haitian Revolution was unthinkable, Michel-Rolph Trouillot argues that "white hegemony is natural and taken for granted; any alternative is still in the domain of the unthinkable" (93). Furthermore, Trouillot states that "archival power... [is] the power to define what is and what is not a serious object of research and, therefore, of mention" (99). The narrators of the novel, as well as the multitude of characters present throughout the text, give themselves the freedom and power to imagine a different world, a different history, not only as an act of survival, but as an act of resistance.

\section{Conclusion}

In Chandra Talpade Mohanty's Feminism Without Borders: Decolonizing Theory, Practicing Solidarity (2003), she points out that women have the power to resist hegemonic narratives in many ways. She explains that

Resistance is encoded in the practices of remembering, and of writing. Agency is thus figured in the small, day-to-day practices and struggles of Third World women... The very practice of remembering against the grain of 'public' or hegemonic history, of locating the silences and the struggle to 
assert knowledge that is outside the parameters of the dominant, suggests a rethinking of sociality itself (83)

Through the practice of rewriting, recreating, and reimagining Wuthering Heights, Condé engages in this resistance against hegemonic colonial discourse. The very act of rewriting is a conscious decision to dismantle stable and limiting identities, renegotiate and redefine colonial discourse, and redirect the literary canon itself to be more inclusive of all stories. 


\section{References}

Ashcroft, Bill, Gareth Griffiths, and Helen Tiffin. The Empire Writes Back: Theory and Practice in Post-Colonial Literatures. Routledge, 1989.

Brontë, Charlotte. Jane Eyre. Dover Publications, 2011.

Brontë, Emily. Wuthering Heights. $4^{\text {th }}$ ed., W.W. Norton \& Company, 2002.

Butler, Judith. Gender Trouble: Feminism and the Subversion of Identity. Routledge, 2006.

Césaire, Aimé. Discourse on Colonialism. Monthly Review Press, 2001.

Condé, Maryse. Crossing the Mangrove. Anchor, 1995.

---. Desirada. Soho Press, 2001.

---. Hérémakhonon. Lynne Rienner Publishers, 1999.

---. I, Tituba, Black Witch of Salem. University of Virginia Press, 2009.

---. Interview by Rebecca Wolff. BOMB Magazine, 01 Jul. 1999, https://bombmagazine.org/articles/maryse-condé/. Accessed on 25 Nov. 2017.

---. "The Stealers of Fire: The French-Speaking Writers of the Caribbean and their Strategies of Liberation." Journal of Black Studies, vol. 35, no. 2, 2004, pp.154-164. JSTOR, JSTOR, www.jstor.org/stable/4129298.

---. Windward Heights. Faber \& Faber Limited, 1998.

Fumagalli, Maria Cristina. "Scapegoating the Mulattos: Maryse Condé's La Migration Des Coeurs." Caribbean Perspectives on Modernity: Returning Medusa's Gaze, University of Virginia Press, 2009, pp. 53-72, www.jstor.org/stable/j.ctt6wrp3c.7.

Githire, Njeri. Cannibal Writes: Eating Others in Caribbean and Indian Ocean Women's Writing. University of Illinois Press, 2014.

Glissant, Édouard, and J. Michael Dash. Caribbean Discourse: Selected Essays. University Press of Virginia, 1989.

Hawthorne, Nathaniel. The Scarlet Letter. Bantam Classics, 1981.

Hazette, Valérie V. Wuthering Heights on Film and Television: A Journey Across Time and Cultures. Intellect Ltd., 2016.

Homer. The Odyssey. Penguin Classics, 1999.

Kaplan, Cora. Victoriana: Histories, Fictions, Criticism. Columbia University Press, 2007. 
Little, Roger. "Condé, Brontë, Duras, Beyala: Intertextuality or Plagiarism?" French Studies Bulletin: A Quarterly Supplement, vol. 72, 1999, pp.13-15. EBSCOhost, Ezproxy.fiu.edu/login?url=http://search.ebscohost.com/login.aspx?direct=t rue $\& d b=m z h \& A N=1999048380 \&$ site=ehost-live $\&$ scope $=$ site.

Loomba, Ania. Colonialism/Postcolonialism. $3^{\text {rd }}$ ed., Routledge, 2015.

Mardorossian, Carine M. Reclaiming Difference: Caribbean Women Rewrite Postcolonialism. University of Virginia Press, 2005.

Micklin, Anna T. "Negritude Movement." BlackPast, n.d. http://www.blackpast.org/gah/negritude-movement

Mohanty, Chandra Talpade. Feminism Without Borders: Decolonizing Theory, Practicing Solidarity. Duke University Press Books, 2003.

Moi, Toril. The Kristeva Reader. Wiley-Blackwell, 1991.

Rhys, Jean. Wide Sargasso Sea. W.W. Norton \& Company, 1998.

Swamy, Vinay. "Traversing the Atlantic: From Brontë's 'Wuthering Heights' to Condé's 'La Migration Des Cœurs." Journal of Caribbean Literatures, vol. 4, no. 2, 2006, pp. 61-74. JSTOR, JSTOR, www.jstor.org/stable/40986192.

Trouillot, Michel-Rolph. Silencing the Past: Power and the Produciton of History. $2^{\text {nd }}$ ed., Beacon Press, 2015.

Walcott, Derek. The Odyssey: A Play. Farrer, Straus and Giroux, 1993. 